\title{
Examination of ability to androgenesis of spring wheat genotypes resistant to Fusarium
}

\author{
Dorota WeigT* ${ }^{*}$ Jerzy Nawracala, Danuta Popowska, Katarzyna NiJak \\ Department of Genetics and Plant Breeding, Poznan University of Life Sciences, Poznań, Poland \\ *Corresponding author: dweigt@up.poznan.pl
}

\begin{abstract}
Diseases caused by fungi from the genus Fusarium constitute a serious problem in spring wheat cultivation. Ear infestation leads reduced yield and plant contamination with mycotoxins. Therefore it is essential to introduce resistance genes to high-yielding cultivars. The generation of double haploid (DH) lines makes it possible to shorten the time required to select favourable genotypes. The aim of this study was to analyze the capacity of plants to regenerate in anther cultures and to generate $\mathrm{DH}$ of spring wheat genotypes that potentially constitute germplasm material for resistance breeding, directed against fungi from the genus Fusarium. The plant material comprised wheat cultivars with increased resistance to Fusarium: Sumai 3, Ning 8331, Norin 52, Frontana, as well as line 8475-59 and high-yielding Polish cultivars: Łagwa, Waluta and Zadra. Spikes were subjected to a thermal shock at $4^{\circ} \mathrm{C}$. Anthers were placed on the $\mathrm{C} 17$ inducing medium. Two combinations of growth regulators, i.e. 2,4-D and kinetin as well as 2,4-D and dicamba were applied. A total of 19,200 anthers were used, resulting in a total of 440 calli from which 352 plants were obtained. Of this number $14 \%$ were albino. The regeneration efficiency ranged from $0 \%$ to $17.33 \%$ depending on the analyzed genotype and the combination of growth regulators in the induction medium. The highest number of green plants and seeds were obtained from cv. Łagwa, Zadra and Sumai 3. Analyses of the regenerants, using a flow cytometer, demonstrated that depending on the genotype, haploids constituted approx 75\% of green plants. Doubling of the number of chromosomes at a $40 \%$ efficiency rate took place when $0.1 \%$ colchicine was used. In the experiment $54 \mathrm{DH}$ lines were obtained from which 283 kernels were collected. The best genotypes for crossing components in terms of their regeneration ability were found to be cultivar Frontana among the cultivars resistant to Fusarium, and cultivar Łagwa from Polish cultivars used in the experiment.
\end{abstract}

Key words: spring wheat, androgenesis, regeneration efficiency, double haploids

\section{Introduction}

Bread wheat is the most commonly grown cereal worldwide and in Poland. Infestation with fungal pathogens from the genus Fusarium leads to reduced yield through the reduction of grain size and the number of kernels in the ear as well as contamination of the plant with mycotoxins that are harmful to human and animal health (Klahr et al., 2007). The European Union Member States are obliged to follow standards concerning toxin content in the grain and its processed products. Most wheat cultivars grown in Europe exhibit high or very high susceptibility to fusariosis (Stępień and Chełkowski, 2005). In Poland, grain contamination with Fusarium mycotoxins is a serious problem and has been frequently reported (Chełkowski et al., 1988). This indicates the need to improve the resistance of wheat cultivars to ear blight caused by Fusarium sp. The sources that may provide that resistance includes spring wheats from China (Sumai 3 and Ning lines), and Brazil, cv. Frontana (Masterhazy, 2002; Wiśniewska and Kowalczyk, 2005). Unfortunately, all these genotypes are characterized by unfavorable yields and poor flour quality (Wiśniewska and Kowalczyk, 2005). The transfer of resistance genes from those cultivars to high-yielding cultivars is connected with crossing and selection of resistant genotypes extended over periods of many years. The application of double haploid (DH) lines makes it possible to shorten the breeding program and facilitates faster selection of desirable genotypes. Unfortunately, producing haploid wheat plants through androgenesis is strongly dependent on the genotype and is not very efficient (Rybczyński et al., 1991; Zamani et al., 2003; Konieczny et al., 2003). Moreover, there are very few reports on the capacity of androgenesis in genotypes that 
are sources of resistance to Fusarium (Masojć et al., 1993). Therefore, the aim of this experiment was to verify the capacity of plant regeneration in anther cultures of spring wheat genotypes as sources of resistance to $F u-$ sarium, as well as crossing them with Polish cultivars.

\section{Materials and methods}

Plant material comprised wheat cultivars that are known sources of resistance to fungal infection caused by fungi from the genus Fusarium: Chinese varieties Sumai 3 and Ning 8331, Japanese cultivar Norin 52, Brazilian cultivar Frontana and line 8475-59 as well as highyielding Polish cultivars: Łagwa, Waluta and Zadra.

Donor plants were grown in the greenhouse in pots. Spikes were excised when microspores were in the medium or late uninuclear stage (Barnabas et al., 2001). The development stage of microspores was determined using smear preparations stained with Belling's fluid. Androgenesis was initiated by subjecting the spikes to thermal stress at $4{ }^{\circ} \mathrm{C}$ for a period of 7 or 14 days. The spikes were sterilized for $4 \mathrm{~min}$ in $4.85 \% \mathrm{NaClO}$. Subsequently, the spikes were rinsed in sterile distilled water. Anthers without filaments were transferred onto the C17-inducing medium (Wang and Chen, 1983). Two combinations of growth regulators were applied: 2,4-Dichlorophenoxyacetic acid (2,4-D) $(1.5 \mathrm{mg} / \mathrm{l})$ with kinetin $(0.5 \mathrm{mg} / \mathrm{l})$, and $2,4-\mathrm{D}(1.0 \mathrm{mg} / \mathrm{l})$ with dicamba $(1.0 \mathrm{mg} / \mathrm{l})$. In each combination the explants were placed on 10 Petri dishes with 60 anthers, collected from one ear, per dish. A total of 19,200 anthers were used (2,400 from each analyzed genotype). The source of carbohydrates was maltose $(90 \mathrm{~g} / \mathrm{l})$. The medium was solidified with gerlite at $2.5 \mathrm{~g} / \mathrm{l}$. The explants were incubated at $3^{\circ} \mathrm{C}$ in the dark.

After 8 weeks the calli were passaged on the MS regeneration medium (Murashige and Skoog, 1962) with an addition of $0.5 \mathrm{mg} / 1$ 1-naphthaleneacetic (NAA) and $0.5 \mathrm{mg} / \mathrm{l} \mathrm{kinetin}$. The dishes were placed in the culture chamber at $24^{\circ} \mathrm{C}$ with a photoperiod of 16 -h light/8-h darkness. After 3-6 weeks, plant regeneration was observed. The regenerants were subsequently passaged to glass flasks to facilitate further growth.

The ploidy level of the obtained plants was analyzed by measuring the nuclear DNA content by laser flow cytometry. For the analysis, young leaves of regenerated plants and of internal standard were chopped simulta- neously with a sharp razor blade in a plastic Petri dish with $0.5 \mathrm{ml}$ nucleus-isolation buffer supplemented with $50 \mu \mathrm{g} / \mathrm{ml}$ ribonuclease (Śliwińska, 2008). The $2 \mathrm{C}$ genome of cv. Muszelka was used as an internal standard. After chopping, the suspension was passed through a 30-50 $\mu \mathrm{m}$ mesh nylon filter and incubated for approximately 30-minutes. Following the incubation, a staining buffer (propidium iodide; $50 \mu \mathrm{g} / \mathrm{ml}$ ) was added and measurements were taken using a Partec flow cytometer (Münster, Germany) equipped with an argon laser (Śliwińska, 2008). Ploidy measurements were conducted at the Department of Molecular Biology and Cytometry, the University of Technology and Life Sciences in Bydgoszcz, Poland.

Selected haploids were placed for $6 \mathrm{~h}$ in a $0.1 \%$ colchicine solution with an addition of DMSO and Tween. Rinsed plants were planted in sterile soil. The plants that set seeds were considered as DH.

The efficiency of callus formation was assessed and found to constitute the average number of calli per 100 placed anthers. The plant regeneration efficiency was calculated as the average number of plants produced per 100 used anthers. Both parameters were expressed as a percentage.

\section{Results}

From all the anthers used, a total of 440 tubercular, cream-colored calli were obtained. Among the genotypes resistant to Fusarium, explants of cv. Ning 8331 formed the greatest number of calli (67) at a regeneration rate of $2.79 \%$. The smallest number of calli was observed for the anthers of cv. Norin 52 - the efficiency of callus formation for this cultivar was $0.25 \%$. Polish cultivars Lagwa, Waluta and Zadra formed a higher number of calli (106, 61, 90, respectively) and the efficiency of this process ranged from $2.54 \%$ to $4.42 \%$. The efficiency of callus formation in Polish cultivars was on an average over 3 -fold higher than that of genotypes resistant to Fusarium (Table 1 ).

Analysis of the effect of growth regulators on callus formation in the tested genotypes revealed that the strongest stimulation of this process was provided by the $\mathrm{C} 17$ medium with $2,4-\mathrm{D}(1.0 \mathrm{mg} / \mathrm{l})$ and dicamba $(1.0 \mathrm{mg} / \mathrm{l})$ following a 7-day thermal stress. In this combination calli were formed most efficiently by Polish cultivars: Waluta and Łagwa, in which the efficiency of callus 
Table 1. Total average efficiency of callus formation of the analyzed spring wheat cultivars

\begin{tabular}{l|c|c|c}
\hline \multicolumn{1}{c|}{ Cultivar } & $\begin{array}{c}\text { Number } \\
\text { of used anthers }\end{array}$ & $\begin{array}{c}\text { Number } \\
\text { of calli }\end{array}$ & $\begin{array}{c}\text { Average efficiency } \\
\text { of callus formation } \\
{[\%]}\end{array}$ \\
\hline Sumai 3 & 2400 & 48 & 2.00 \\
\hline Ning 8331 & 2400 & 67 & 2.79 \\
\hline Norin 52 & 2400 & 6 & 0.25 \\
\hline Frontana & 2400 & 48 & 2.00 \\
\hline $8475-59$ & 2400 & 14 & 0.58 \\
\hline Łagwa & 2400 & 106 & 4.42 \\
\hline Waluta & 2400 & 61 & 2.54 \\
\hline Zadra & 2400 & 90 & 3.75 \\
\hline Total & 19200 & 440 & 2.29 \\
\hline
\end{tabular}

Table 2. The effect of growth regulators and spikes pretreatment on the efficiency of callus formation and green plant regeneration in the analyzed spring wheat genotypes

\begin{tabular}{|c|c|c|c|c|c|c|c|c|}
\hline \multirow[b]{3}{*}{ Cultivar } & \multicolumn{4}{|c|}{ Average efficiency of callus formation [\%] } & \multicolumn{4}{|c|}{ Average efficiency of green plant regeneration [\%] } \\
\hline & \multicolumn{2}{|c|}{$\begin{array}{c}\text { spikes pretreatment } 7 \\
\text { days at } 4^{\circ} \mathrm{C}\end{array}$} & \multicolumn{2}{|c|}{$\begin{array}{l}\text { spikes pretreatment } 14 \\
\text { days at } 4^{\circ} \mathrm{C}\end{array}$} & \multicolumn{2}{|c|}{$\begin{array}{c}\text { spikes pretreatment } 7 \\
\text { days at } 4^{\circ} \mathrm{C}\end{array}$} & \multicolumn{2}{|c|}{$\begin{array}{c}\text { spikes pretreatment } 14 \\
\text { days at } 4^{\circ} \mathrm{C}\end{array}$} \\
\hline & $\begin{array}{c}\mathrm{C} 17 \\
\text { medium } \\
+2,4-\mathrm{D} \\
(1.5 \mathrm{mg} / \mathrm{l}) \\
+ \text { kinetin } \\
(0.5 \mathrm{mg} / \mathrm{l})\end{array}$ & $\begin{array}{c}\mathrm{C} 17 \\
\text { medium } \\
+2,4-\mathrm{D} \\
(1.0 \mathrm{mg} / \mathrm{l}) \\
+ \text { dicamba } \\
(1.0 \mathrm{mg} / \mathrm{l})\end{array}$ & $\begin{array}{c}\mathrm{C} 17 \\
\text { medium } \\
+2,4-\mathrm{D} \\
(1.5 \mathrm{mg} / \mathrm{l}) \\
+ \text { kinetin } \\
(0.5 \mathrm{mg} / \mathrm{l})\end{array}$ & $\begin{array}{c}\mathrm{C} 17 \\
\text { medium } \\
+2,4-\mathrm{D} \\
(1.0 \mathrm{mg} / \mathrm{l}) \\
+ \text { dicamba } \\
(1.0 \mathrm{mg} / \mathrm{l})\end{array}$ & $\begin{array}{c}\mathrm{C} 17 \\
\text { medium } \\
+2,4-\mathrm{D} \\
(1.5 \mathrm{mg} / \mathrm{l}) \\
+ \text { kinetin } \\
(0.5 \mathrm{mg} / \mathrm{l})\end{array}$ & $\begin{array}{c}\mathrm{C} 17 \\
\text { medium } \\
+2,4-\mathrm{D} \\
(1.0 \mathrm{mg} / \mathrm{l}) \\
+ \text { dicamba } \\
(1.0 \mathrm{mg} / \mathrm{l})\end{array}$ & $\begin{array}{c}\mathrm{C} 17 \\
\text { medium } \\
+2,4-\mathrm{D} \\
(1.5 \mathrm{mg} / \mathrm{l}) \\
+ \text { kinetin } \\
(0.5 \mathrm{mg} / \mathrm{l})\end{array}$ & $\begin{array}{c}\mathrm{C} 17 \\
\text { medium } \\
+2,4-\mathrm{D} \\
(1.0 \mathrm{mg} / \mathrm{l}) \\
+ \text { dicamba } \\
(1.0 \mathrm{mg} / \mathrm{l})\end{array}$ \\
\hline Sumai 3 & 1.00 & 4.67 & 0.83 & 1.50 & 0.00 & 6.67 & 0.00 & 0.00 \\
\hline Ning 8331 & 1.00 & 6.33 & 0.83 & 3.00 & 0.00 & 0.00 & 0.00 & 0.00 \\
\hline Norin 52 & 1.00 & 0.00 & 0.00 & 0.00 & 0.00 & 0.00 & 0.00 & 0.00 \\
\hline Frontana & 4.33 & 0.50 & 0.17 & 3.00 & 17.33 & 0.00 & 0.00 & 0.00 \\
\hline $8475-59$ & 0.83 & 0.00 & 0.67 & 0.83 & 0.00 & 0.00 & 0.00 & 0.50 \\
\hline Łagwa & 0.50 & 8.50 & 0.83 & 7.83 & 0.33 & 13.67 & 0.00 & 8.33 \\
\hline Waluta & 0.00 & 10.00 & 0.17 & 0.00 & 0.00 & 2.50 & 0.00 & 0.00 \\
\hline Zadra & 7.50 & 0.67 & 1.83 & 5.00 & 0.50 & 0.00 & 0.00 & 1.33 \\
\hline
\end{tabular}

tissue formation was $10.0 \%$ and $8.5 \%$, respectively. Among cultivars which were sources of resistance to Fusarium in this combination, calli were formed most efficiently by plants of cv. Ning 8331 and Sumai 3 , at an efficiency rate of $6.33 \%$ and $4.67 \%$, respectively. In turn, plants from Polish cv. Zadra and Brazilian cv. Frontana formed the highest number of calli on the $\mathrm{C} 17$ medium with an addition of 2,4-D (1.5 mg/l $)$ and kinetin $(0.5 \mathrm{mg} / \mathrm{l})$ after 7 days of ear pretreatment. The number of calli per 100 used anthers was 7.5 and 4.33, respecti- vely. The lowest number of calli was observed on the medium containing 2,4-D and kinetin after a 14-day thermal stress, on which callus formation occurred at a rate ranging from $0 \%$ on anthers of Fusarium-resistant cv. Norin 52 to $1.83 \%$ on explants from Polish cv. Zadra (Table 2).

In this study, from a total of 440 calli, 352 plants were regenerated, of which $14 \%$ presented chlorophyll defects. The greatest number of green plants was regenerated from calli of Polish cv. Łagwa and Brazilian cv. 
Frontana as sources of resistance, at 134 and 104 plants, respectively. Regeneration was not observed on the explants of cv. Norin 52, while from calli of cv. Ning 8331 only albino plants were obtained. The regeneration efficiency of green plants from Polish cultivars was greater than that of the genotypes resistant to Fusarium (Table 3).

Among genotypes that are sources of Fusarium resistance, the greatest number of green plants regenerated from the calli of cv. Frontana, but in this case regeneration occurred only on the $\mathrm{C} 17$ medium with an addition of 2,4-D $(1.5 \mathrm{mg} / \mathrm{l})$ and kinetin $(0.5 \mathrm{mg} / \mathrm{l})$ following a 7-day thermal stress. The efficiency of regeneration was $17.3 \%$. Among genotypes resistant to Fusarium, high regeneration rates of green plants $(6.67 \%)$ was also observed for calli of cv. Sumai 3 on the $\mathrm{C} 17$ medium with an addition of 2,4-D and dicamba after 7 days of ear exposure to low temperature. Polish cultivars Łagwa and Waluta formed the highest number of green plants in the same combination of growth regulators and thermal stress duration. The efficiency of regenerant formation was $13.67 \%$ and $2.5 \%$, respectively. In turn, the regeneration of plants from cv. Zadra and line 8475-59 was most efficient after a 14-day ear treatment at low temperature, on a medium with an addition of dicamba (regeneration rate of $8.33 \%$ and $0.5 \%$, respectively). The $\mathrm{C} 17$ medium, with an addition of 2,4-D and kinetin after a 14-day ear exposure to low temperature did not stimulate regeneration in any of the tested cultivars (Table 2).

The ploidy level was determined for a total of 210 plants. The other regenerants were rejected because after transfer to the soil, their development was inhibited or they displayed accelerated earing. A considerable number of plants subjected to the measurement of DNA content in the nuclei were haploids (75.71\%). It was found that 46 plants were diploid and 5 tetraploid (Table 4). The highest number of haploids was obtained from cv. Łagwa (86) and Frontana (52). All haploids were subjected to colchicine treatment and in this way 54 plants with a doubled number of chromosomes were obtained. Thirty plants were generated from the Polish cv. Łagwa, 23 from cv. Frontana carrying Fusarium resistance genes, while one plant developed from line 8475-59. Thus the effectiveness of colchicine treatment was $40 \%$. All the obtained DH lines set seeds. The number of kernels in an ear ranged from 1 to 19. Among the total of 283 kernels, 174 were produced from cv. Łagwa, 101 from cv. Frontana and 8 from line 8475-59.

\section{Discussion}

Plant genotype is a major factor influencing the capacity of androgenesis (Lazar et al., 1984; Tuvesson et al., 1989). In the conducted study these observations were definitely confirmed. Eight tested spring wheat genotypes differed considerably, both in terms of their ability to form calli and the efficiency of regeneration of green and albino plants. Polish cultivars formed, on an average, 3 times more calli than Fusarium-resistant genotypes. Similar to many other studies, the average efficiency of callus tissue formation was low, ranging from $0.25 \%$ for Fusarium-resistant cv. Norin 52 to $4.42 \%$ for the Polish cv. Łagwa.

A similarly low efficiency has been reported by Konieczny et al. (2003) who obtained from 0.19 calli per 100 used anthers of Polish cv. Wanda to 9.07 of cv. Apollo. The varied capacity for callus tissue formation in wheat, from 2.66 to 14.91 structures per 100 used anthers, has also been observed by Zamani et al. (2003). In turn, in the experiments conducted by Ponitka and Ślusarkiewicz-Jarzina (2009) in oat anther cultures, the callus tissue was formed with an efficiency ranging from 0 to 12.1 structures per 100 anthers.

Even greater genotypic differences were found in the efficiency of regeneration of green plants. No such plants were regenerated from the two Fusarium-resistant genotypes, i.e. Ning 8331 and Norin 52 . Failure of plant regeneration from cv. Ning 8331 in the experiment conducted by Masojć et al. (1993) confirms poor capacity for androgenesis in the case of this cultivar. Masojć et al. (1993) did not obtain plants from cv. Sumai 3, but in the studies conducted using the $\mathrm{C} 17$ inducing medium, the average efficiency of regeneration of green plants in this cultivar was $1.67 \%$, while in the variant with an addition of 2,4-D and dicamba after 7 days of spike pretreatment it was $6.5 \%$. Thus it is very likely that Fusarium-resistant cultivars Norin 52 and Ning 8331, from which no plants were obtained, require other inducing media. The lack of response of wheat genotypes to the induction of androgenesis has been reported by many authors. Tuvesson et al. (2000) tested 257 winter wheat lines, of which 186 formed green plants at the efficiency of regeneration ranging from $0 \%$ to $34.4 \%$. 
Table 3. Total average efficiency of plant regeneration of the analyzed spring wheat cultivars

\begin{tabular}{l|c|c|c|c|c}
\hline \multicolumn{1}{|c|}{ Cultivar } & $\begin{array}{c}\text { Number } \\
\text { of used anthers }\end{array}$ & $\begin{array}{c}\text { Number } \\
\text { of albino plants }\end{array}$ & $\begin{array}{c}\text { Average efficiency } \\
\text { of albino plant } \\
\text { regeneration } \\
{[\%]}\end{array}$ & $\begin{array}{c}\text { Number } \\
\text { of green plants }\end{array}$ & $\begin{array}{c}\text { Average efficiency } \\
\text { of green plant } \\
\text { regeneration } \\
{[\%]}\end{array}$ \\
\hline Sumai 3 & 2400 & 1 & 0.04 & 40 & 1.67 \\
\hline Ning 8331 & 2400 & 18 & 0.75 & 0 & 0.00 \\
\hline Norin 52 & 2400 & 0 & 0.00 & 0 & 0.00 \\
\hline Frontana & 2400 & 3 & 0.13 & 104 & 4.33 \\
\hline $8475-59$ & 2400 & 1 & 0.04 & 3 & 0.13 \\
\hline Lagwa & 2400 & 12 & 0.50 & 134 & 5.58 \\
\hline Waluta & 2400 & 6 & 0.25 & 15 & 0.63 \\
\hline Zadra & 2400 & 7 & 0.29 & 8 & 0.33 \\
\hline Total & 19200 & 48 & 0.25 & 304 & 1.58 \\
\hline
\end{tabular}

Table 4. Ploidy level of regenerants of the analyzed spring wheat cultivars

\begin{tabular}{l|c|c|c|c|c}
\hline \multicolumn{1}{c|}{ Cultivar } & $\begin{array}{c}\text { Number } \\
\text { of green plants }\end{array}$ & $\begin{array}{c}\text { Number } \\
\text { of analyzed plants }\end{array}$ & Haploids & Diploids & Tetraploids \\
\hline Sumai 3 & 40 & 17 & 15 & 2 & 0 \\
\hline Ning 8331 & 0 & 0 & 0 & 0 & 0 \\
\hline Norin 52 & 0 & 0 & 0 & 0 & 0 \\
\hline Frontana & 104 & 73 & 52 & 19 & 2 \\
\hline $8475-59$ & 3 & 3 & 3 & 0 & 0 \\
\hline Lagwa & 134 & 103 & 86 & 17 & 0 \\
\hline Waluta & 15 & 6 & 2 & 1 & 3 \\
\hline Zadra & 8 & 8 & 1 & 7 & 0 \\
\hline Total & 304 & 210 & 159 & 46 & 5 \\
\hline
\end{tabular}

In turn, Adamski et al. (2009) did not obtain plants from 5 out of 33 tested genotypes, Chaudhary et al. (2003) obtained green plants from 6 genotypes from 11 tested cultivars, while Ljevanaić et al. (2006) observed regeneration in 7 out of 8 tested genotypes. The efficiency of green plant regeneration from anthers was low, with an average for all the tested genotypes $1.58 \%$. Similar regeneration efficiency at $1.8 \%$ was observed by Adamski et al. (2009). In the present study, variations of the regeneration efficiency between genotypes were evident, ranging from $0 \%$ up to $5.58 \%$ on an average, similar, to the results of studies conducted by other authors (Adamski et al., 2009; Chaudhary et al., 2003; Masojć et al., 1993). The efficiency of plant regeneration from Polish cultivars was greater than from Fusarium-resistant genotypes.
The induction of changes in microspore development requires a stress stimulus. For this purpose, pretreatment is applied to provide appropriate physiological conditions for the microspore (Śnieżko, 1991). In this experiment, spikes were subjected to a 7 and 14 day thermal stress at $4{ }^{\circ} \mathrm{C}$. Both, callus formation and regeneration of green plants, occurred more efficiently on the application of a shorter cold temperature treatment. Only the calli obtained from line 8475-59 and cv. Zadra formed more green plants after 14 days of thermal stress. This result confirmed earlier observations of many authors that androgenesis ability and efficiency of plant regeneration depends mainly on the plant genotype. Kim et al. (2003) recommended shorter stress duration - from 1 to 5 days for two spring wheat cultivars (Bobwhite and Pavon 76). The same period of time 
was recommended Chaudhary et al. (2003) who tested nine lines of winter wheat, two of spring wheat and $18 \mathrm{~F}_{1}$ hybrids. In turn, Redha and Talaat (2008) proposed a longer exposure to low temperature for the spikes from 7 to 10 days. They investigated four hexaploid spring wheat genotypes. In contrast, Pauk et al. (2003) suggested that a thermal shock for wheat should last as long as 14 days. Datta (2005) tested factors controlling crop development and recommended, for wheat, increasing the temperature to $8^{\circ} \mathrm{C}$ for approx. 10 to 14 days.

For the androgenesis induction, the presence of exogenous auxin is required, which may be applied together with cytokinines inducing cell division. In the present study, 2,4-D was added to both tested media at $1.0 \mathrm{mg} / 1$ or $1.5 \mathrm{mg} / \mathrm{l}$ in order to initiate the process of androgenesis. Regeneration was observed only through indirect embryogenesis. Zheng and Konzak (1999) observed callus induction with no involvement of 2,4-D. However, the number of formed structures was low and they did not display the capacity for plant regeneration. The same authors also stated that $1-2 \mathrm{mg} / \mathrm{l}$ was the most appropriate concentration of 2,4-D in the inducing medium. A too high concentration $(4 \mathrm{mg} / \mathrm{l})$ resulted in the loss of callus formation or plant regeneration.

In order to improve the androgenesis efficiency, the induction medium was supplemented with $0.5 \mathrm{mg} / \mathrm{l}$ kinetin or $1.0 \mathrm{mg} / 1$ dicamba, added to the already present 2,4-D. Among the 8 tested genotypes, 4 formed more calli on the medium with dicamba and 4 with kinetin, while in 5 out of the 6 regenerating genotypes, regeneration of green plants was more efficient on a medium with an addition of dicamba. Satyavathi et al. (2004), when investigating the effect of 2,4-D, dicamba and picloram on callus induction and plant regeneration in blastodisc cultures of durum wheat, recorded the highest callus induction and plant regeneration on a medium containing $2 \mathrm{mg} / \mathrm{l}$ dicamba. In turn, Immonen and Anttila (1998) replaced 2,4-D dicamba in the combination with kinetin and observed that the percentage of the formed calli, embryos and green plants by anthers was the same as in case of 2,4-D application. Hassawi et al. (1999) investigated the effect of three different auxins $(2 \mathrm{mg} / 1$ 2,4-D, $2 \mathrm{mg} / \mathrm{l}$ dicamba or $2 \mathrm{mg} / \mathrm{l}$ picloram) and $1 \mathrm{mg} / \mathrm{l}$ kinetin on the response of wheat and triticale in anther cultures. The highest percentage of responding anthers was observed on the medium with 2,4-D and kinetin (13.9\%), followed by the medium with picloram and kine- tin (11.5\%), while it was the lowest for the combination of 2,4-D and dicamba (10.1\%). This study does not confirm these observations, since a higher efficiency of callus formation was recorded on a medium with 2,4-D and dicamba (depending on the genotype, ranged from $0 \%$ to $10 \%)$. In comparison, the efficiency of callus induction on the medium with 2,4-D and kinetin ranged from $0 \%$ to $7.5 \%$. A positive effect of kinetin, in combination with 2,4-D, was evident for the anthers of cv. Frontana which regenerated into green plants most efficiently (17.33\%). Rakoczy-Trojanowska et al. (1996), while investigating a different combination of inducing media: $2 \mathrm{mg} / 12,4-\mathrm{D}$, $0.5 \mathrm{mg} / \mathrm{l} \mathrm{kinetin}$ and $3 \mathrm{mg} / \mathrm{l}$ picloram, also observed the highest plant regeneration efficiency on a medium containing 2,4-D and kinetin (a total of 33 plants, including 24 albino). In this study we observed a varied response of genotypes to the composition and concentration of growth regulators in the induction medium.

\section{Conclusions}

1) All the studied Polish wheat cultivars demonstrated the ability to form calli and to generate green plants. Genotypes resistant to Fusarium showed a lower capacity of androgenesis in comparison to the Polish cultivars.

2) As suspected, investigated cultivars displayed a diverse reaction to the applied combinations of growth regulators. On an average the regeneration of calli and green plants was found most effective on the $\mathrm{C} 17$ medium with an addition of $1.0 \mathrm{mg} / 1$ 2,4-D and $1.0 \mathrm{mg} / \mathrm{l}$ dicamba after 7 days of ear pretreatment at temperatures lowered to $4^{\circ} \mathrm{C}$. In turn, cv. Frontana regenerated green plants only on the $\mathrm{C} 17$ medium with an addition of $1.5 \mathrm{mg} / 1$ 2,4-D and $0.5 \mathrm{mg} / \mathrm{l}$ kinetin.

3) Cultivar Frontana, among cultivars resistant to Fusarium, and cultivar Łagwa from Polish cultivars proved to be the best genotypes for crossing components, in terms of their regeneration ability.

\section{References}

Adamski T., Surma M., Ponitke A., Ślusarkiewicz-Jarzina A., Krystkowiak K., Kuczyńska A., Pudelska H., Rubrycki K., Trzeciak R., Woźna J. (2009) Production efficiency of wheat haploids by anther culture and wheat $\times$ maize crosses. Biuletyn IHAR 252: 73-80.

Barnabas B., Szakacs E., Karsai I., Bedö Z. (2001) In vitro androgenesis of wheat: from fundamentals to practical application. Euphytica 119: 211-216. 
Chaudhary H.K., Dhaliwal I., Singh S., Sethi G.S. (2003) Genetics of androgenesis in winter and spring wheat genotypes. Euphytica 132: 311-319.

Chełkowski J., Visconti A., Perkowski J., Wakuliński W., Bottalico A. (1988) Mycotoxins and fungi accompanying wheat head fusariosis in Poland. Mycotoxin Res., Fusarium Seminar: 57- 60 .

Datta S.K. (2005) Androgenic haploids: Factors controlling development and its application in crop improvement. Curr. Sci. 89: 1870-1878.

Hassawi D., Qi J., Liang G.H. (1999) Effects of growth regulator and genotype on production of wheat and triticale polyhaploids from anther culture. Plant Breeding 104: 40-45.

Immonen S., Anttila A. (1998) Impact of microspore developmental stage on induction and plant regeneration in rye anther culture. Plant Sci. 139: 213-222.

Kim K.M., Baenziger S.P., Rybczynski J.J. (2003) Characterization of ploidy levels of wheat microspore-derived plants using laser flow cytometry. In Vitro Cell. Dev. Biol. Plant 39: 663-668.

Klahr A., Zimmermann G., Wenzel G., Mohler V. (2007) Effects of environment, disease progress, plant height and heading date on the detection of QTLS for resistance to Fusarium head blight in an European winter wheat cross. Euphytica 154: 17-28.

Konieczny R., Czaplicki A.Z., Golczyk H., Przywara L. (2003) Two pathways of plant regeneration in wheat anther culture. Plant Cell, Tissue Organ Cult. 73: 177-187.

Lazar M.D., Schaeffer W., Baenziger P.S. (1984) Cultivar and cultivar $x$ environment on the development of callus polyhaploid plants from anther cultures of wheat. Theor. Appl. Genet. 67: 273-277.

Ljevnaić B., Kondić-Sipka A., Kobiljski B., Dencić S. (2006) Androgenous ability of heterozygous wheat genotypes and cytological characteristics of green regenerants. Genetika 38(2): 153-158.

Masojć P., Lukow O.M., McKenzie R.I.H., Howes N.K. (1993) Responsiveness to anther culture in cultivars and $F 1$ crosses of spring wheat. Can. J. Sci. 73: 777-783.

Mesterhazy A. (2002) Theory and practice of the breeding for Fusarium head blight resistance in wheat. J. Appl. Genet. 43A: 289-302.

Murashige T., Skoog F. (1962) A revised medium for rapid growth and bioassays with tobacco tissue cultures. Physiol. Plant 15(3): 473-497.

Pauk J., Mihály R., Puolimatka M. (2003) Protocol for wheat (Triticum aestivum L.) anther culture. In: Doubled Haploid Production in Crop Plants, ed. Małuszyński M., Kasha K.J., Forster B.P., Szarejko I., Kluwer Academic Publisher, pp. 59-64.
Ponitka A., Ślusarkiewicz-Jarzina A. (2009) Regeneration of oat androgenic plants in relation to induction media and culture conditions of embryo-like structures. Acta Soc. Botan. Polon. 78: 209-213.

Rakoczy-Trojanowska M., Kwaśniak A., Malepszy S. (1996) Factors influencing viability and sporophytic development in vitro of rye (Secale cereale L.) microspores. Vortr. Pflanzenzüchtg. 35: 256-257.

Redha A., Talaat A. (2008) Improvement of green plant regeneration by manipulation of anther culture induction medium of hexaploid wheat. Plant Cell Tiss Organ. Cult. 92: 141-146.

Rybczyński J.J., Simonson R.L., Baezinger P.S. (1991) Evidence for microspore embryogenesis in wheat anther culture In vitro Cell. Dev. Biol. 27P: 168-174

Satyavathi V.V., Jauhar P.P., Elias E.M., Rao M.B. (2004) Effects of growth regulators on in vitro plant regeneration in durum wheat. Crop Sci. 44: 1839-1846.

Stępień Ł., Chełkowski J. (2005) Identification of resistance for spike fusariosis loci in wheat (Triticum aestivum L.) using DNA markers. In: Genomic and Bioinformatics of Plants, ed. Chełkowski J., Koczyk G., Institute of Plants Genetics, Polish Academy of Sciences, Poznań, pp. 159178

Śliwińska E. (2008) Estimation of DNA Content in Plants Using Flow Cytometry. Post. Biol. Kom. T 35 Suppl. 24: 165-176.

Śnieżko R. (1991) Anthers and pollen cultured in vitro culture. Wiad. Botan. 35: 23-33.

Tuvesson I.K.D., Pedersen S., Andersen S.B. (1989) Nuclear genes affected albinism in wheat (Triticum aestivum L.) anther culture. Theor. Appl. Genet. 78: 879-883.

Tuvesson S., Ljungberg A., Johansson N., Karlsson K.E., Suijs L.W., Josset J.P. (2000) Large-scale production of wheat and triticale double haploids through the use of a singleanther culture method. Plant Breeding 119: 455-459.

Wang P., Chen Y. (1983) Preliminary study on production of height of pollen H2 generation in winter wheat grown in the field. Acta Agron. Sin. 9: 283-284.

Wiśniewska H., Kowalczyk K. (2005) Resistance of cultivars and breeding lines of spring wheat to Fusarium culmorum and powdery mildew. J. Appl. Genet. 46: 35-40.

Zamani I., Gouli-Vavdinoudi E., Kovacs G., Xynias I., Roupakias D., Barnabas B. (2003) Effect of parental genotypes and colchicine treatment on the androgenic response of wheat F1 hybrids. Plant Breeding 122: 314-317.

Zheng M.Y., Konzak C.F. (1999) Effect of 2,4 dichlorophenoxyacetic acid on callus induction and plant regeneration in anther culture of wheat (Triticum aestivum L.). Plant Cell Rep. 19: 69-73. 